\title{
First record of Botryococcus braunii Kützing from Namibia
}

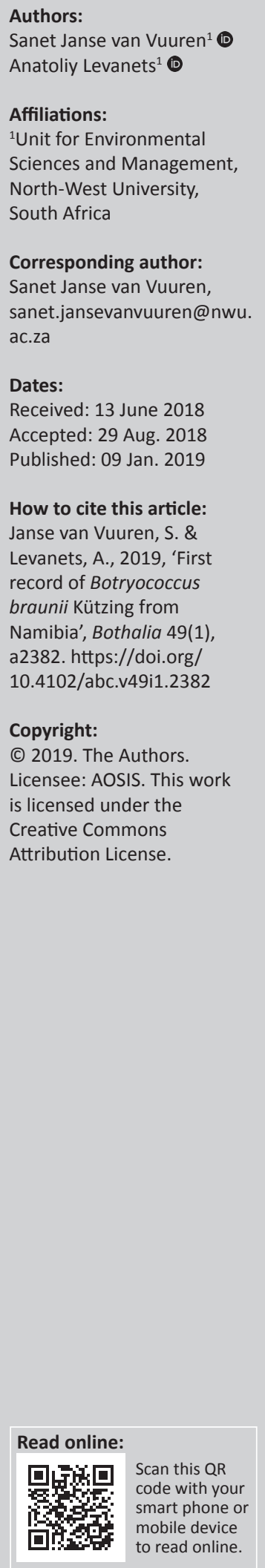

Background: Botryococcus braunii is well known from all continents, but it has been sparsely recorded from Africa compared to other continents. The alga recently formed a rusty orangered bloom in the Tilda Viljoen Dam, situated near Gobabis in Namibia. Blooms of this species are known to produce allelopathic substances that inhibit the growth and diversity of other phytoplankton, zooplankton and fish.

Objectives: The objective of this study was to record the presence of B. braunii in Namibia.

Method: Morphological features of the species were compared with illustrations and literature on B. braunii found in other continents of the world, particularly North America and Europe. Extensive literature surveys revealed its currently known geographical distribution.

Results: The organism responsible for the discolouration of the water was identified as B. braunii. Microscopic examination revealed large colonies that floated in a thick layer on the surface of the water. Literature searches on the geographical distribution of B. braunii revealed that this was the first record of this species' presence in Namibia.

Conclusion: The known geographical distribution of $B$. braunii was expanded to include Namibia.

\section{Introduction}

Under suitable environmental conditions, Botryococcus braunii may form significant blooms. Colony densities as high as 55300 colonies/L were recorded in Nozha Lake, Egypt (Labib et al. 2014), while a bloom in the Darwin Reservoir, Australia, was estimated to weigh 1500 tonnes (fresh mass; Wake \& Hillen 1980). During bloom formation, cells often rise to the surface where they float in a thick layer as a result of the production of lipids (Qin 2005). The bloom in Nozha Lake, Egypt, ranged in colour from green at the start, to orange or red towards the peak and end (Labib et al. 2014). Senousy, Beakes and Hacks (2004) found that some biochemical strains possess the orange-red pigment while others do not and thus appear green.

Significant negative linear relationships between phytoplankton biomass and species diversity have been demonstrated by several authors (e.g. Todd et al. 2014). Decreases in phytoplankton diversity during blooms are, in turn, responsible for decreases in zooplankton diversity (Bockwoldt et al. 2017). In addition, B. braunii blooms can influence biodiversity because it has allelopathic toxic effects on a variety of aquatic organisms. Chiang, Huang and Wu (2004) and Wu et al. (2006) investigated allelochemicals secreted by $B$. braunii and found that a mixture of free fatty acids secreted by this species results in decreasing diversity of other phytoplankton, zooplankton and fish. Blooms of this alga are also associated with fish mortalities in several parts of the world, such as Taiwan (Liyu Lake; Chiang et al. 2004), the Philippines (Paoay Lake; Papa et al. 2008) and Egypt (Nozha Lake; Labib et al. 2014).

B. braunii is widespread in fresh and brackish water bodies in most parts of the world. In contrast to its wide distribution in other continents, it was only described from 12 countries in Africa, of which only two, South Africa and Mozambique, were located in southern Africa. During 2017 a dense bloom of B. braunii developed in the Tilda Viljoen Dam, Namibia. The bloom was monospecific, and B. braunii outcompeted all other phytoplankton species in the dam at the time of the bloom. The bloom rendered a rusty orange-red colour to the water (Figure 2a) and a thick scum (Figure 2b) developed on the surface of the water. Literature searches revealed no known record of the presence of this species in Namibia. 


\section{Study area, research materials and methods}

\section{Study area}

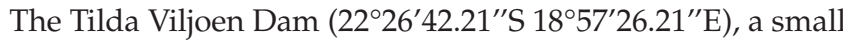
rock-fill dam with a concrete outlet, is situated near Gobabis in Namibia (Figure 1). It supplies drinking water to Gobabis. The dam was completed in 1964, the dam wall has a height of $14 \mathrm{~m}$ and a length of $630 \mathrm{~m}$. The full supply capacity is 1.224 million $\mathrm{m}^{3}$ and it has a surface area of $1.9 \mathrm{~km}^{2}$.

\section{Materials and methods}

A visible orange-red discolouration of the surface water of Tilda Viljoen Dam (Figure 2a) was observed during November 2017 and it lasted for three months until February 2018, where after it gradually subsided. A 1-L grab sample was taken from the surface of the dam at the onset of the bloom on 15 November 2017 and the unpreserved sample was dispatched to the North-West University, Potchefstroom, for algal identification. Algae were identified to species level with a Zeiss light microscope ( $\times 400$ magnification), equipped with a digital camera and eyepiece graticule. Measurements of cell and colony sizes were made by means of a ruler in one of the eyepieces.

\section{Ethical considerations}

\section{Permits}

Collection of algal material in Namibia is not currently regulated by specific legislation and no permits are required.

\section{Taxonomic treatment}

Botryococcus braunii Kützing in Kützing 1849:892.

Type: SWITZERLAND, in lacu Neoburgense, Helvetiae (Lake Neuenburg, also known as Lake Neuchatel), Kützing 1849:892, Type: A. Braun 115; L? Notes: Isotype: UC 790500.

\section{Description}

The genus Botryococcus has a long history of study, accompanied by many classification difficulties. It was first included in the Palmellaceae (Kützing 1849), then listed as part of the

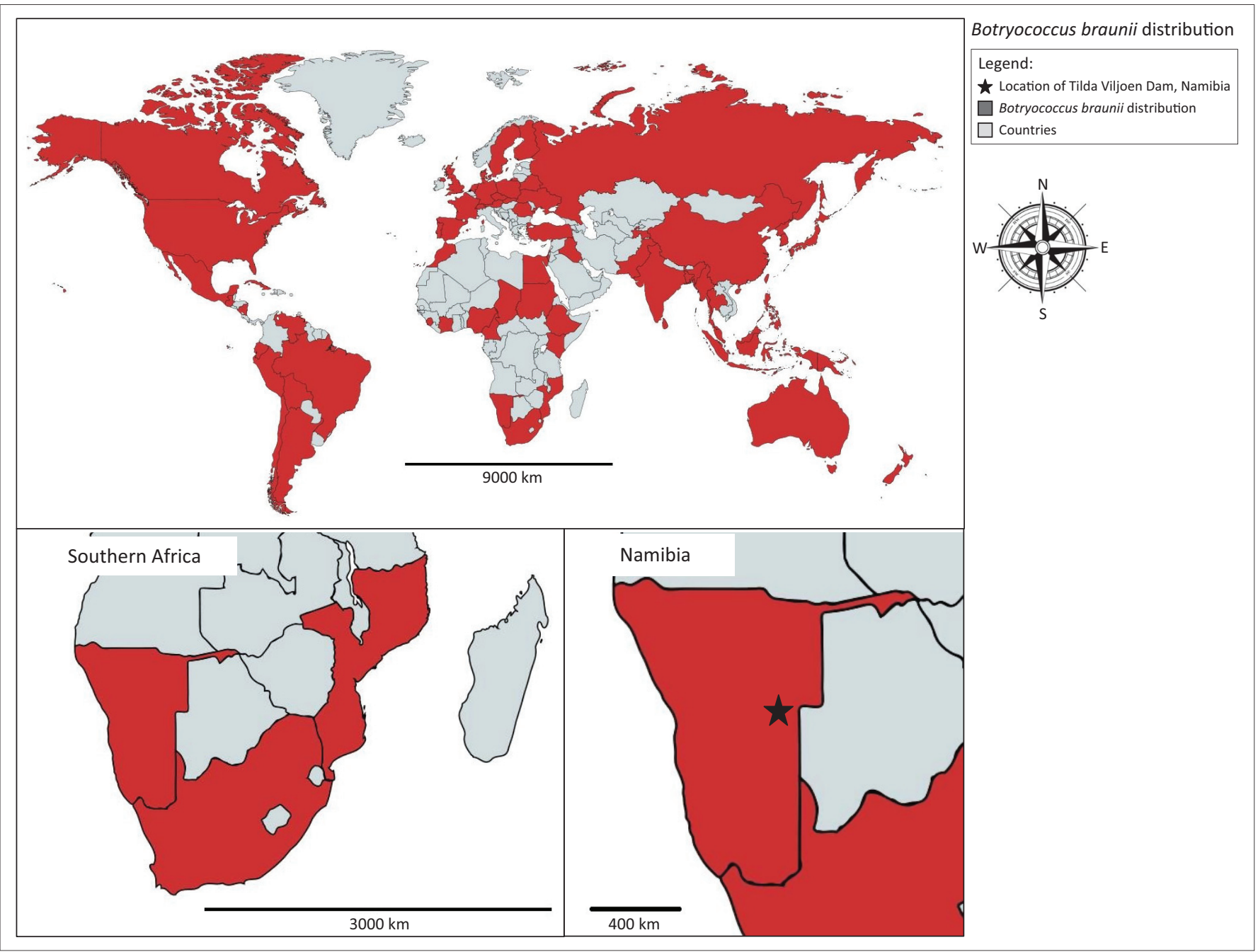

Source: Available from https://mapchart.net/world.html

$\mathrm{km}$, kilometres.

FIGURE 1: Current known distribution of Botryococcus braunii. Map created with mapchart.net. 

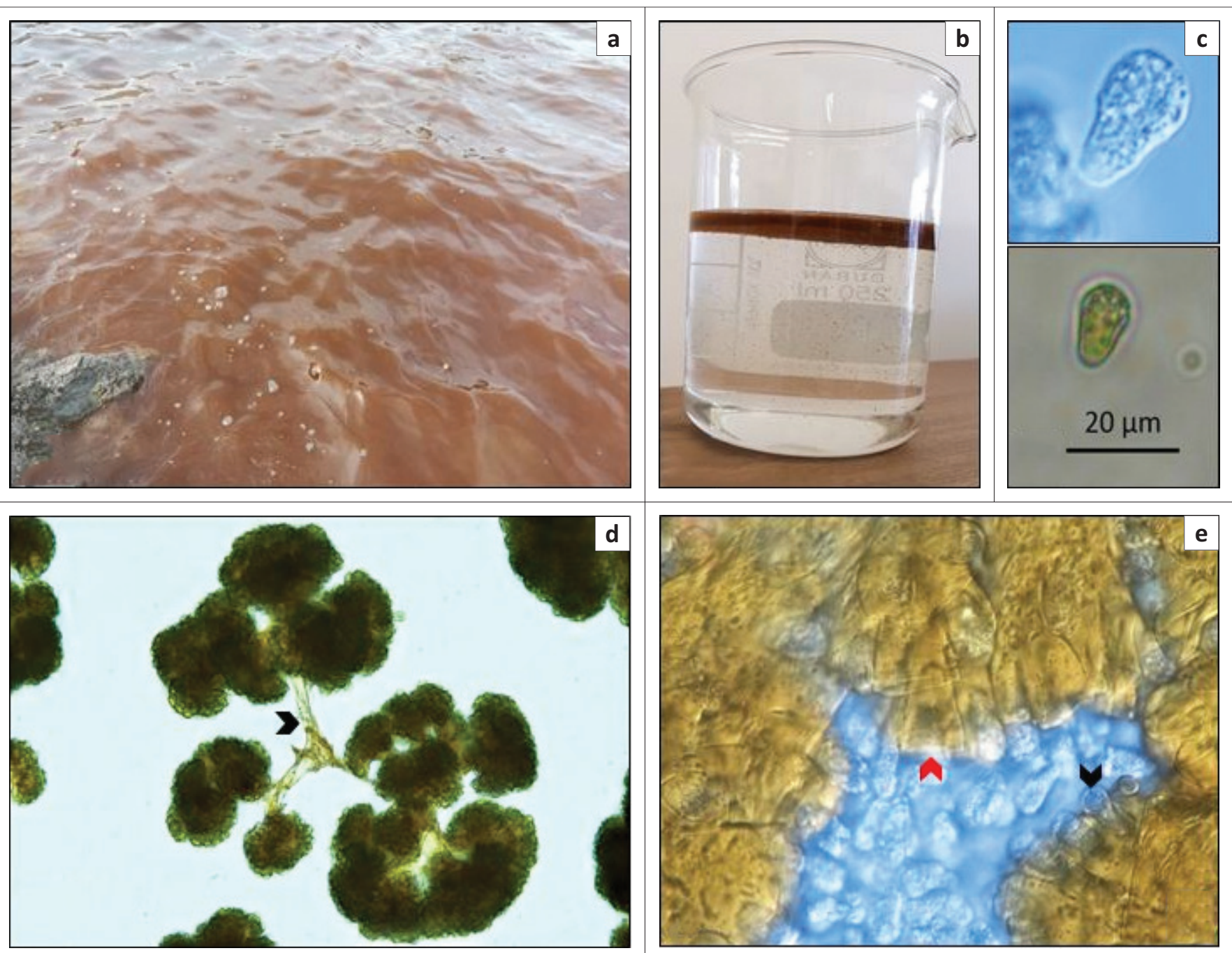

FIGURE 2: Field-, laboratory- and light microscope images of Botryococcus braunii. Diagnostic features are indicated with arrows. (a) Surface water of Tilda Viljoen Dam at the peak of the B. braunii bloom; (b) macroscopic B. braunii colonies floating in a layer on the surface; (c) structure of individual cells; (d) light microscope image of B. braunii colonies with subcolonies and linking threads (black arrow); and (e) cells embedded in cup-shaped structures (black arrow) and empty cups after cells have been released (red arrow)

Tetrasporaceae (Klebs 1883, cited in Blackburn 1936) and Xanthophyceae (Pascher 1939). Blackburn (1936) noticed starch inside the cells and that, together with the identification of chlorophyll b (Belcher \& Fogg 1955), finalised classification within the Phylum Chlorophyta. Currently, the genus is classified under the Phylum Chlorophyta, Class Trebouxiophyceae, Order Trebouxiales and Family Botryococcaceae (Guiry \& Guiry 2018). Komárek and Marvan (1992) established and described differences between at least 13 Botryococcus species based on morphology. The identity of several of these species has, however, been questioned based on variability demonstrated in culture studies by Plain et al. (1993). The two most common and widely distributed species are Botryococcus braunii and Botryococcus protuberans. Besides small differences in cell sizes and colony morphology (Rai et al. 2007), the most apparent difference between these two species is that the cells of B. braunii are embedded in the periphery of mucilaginous masses, while those of $B$. protuberans are prominently projecting from it (John, Whitton \& Brook 2002).

The colonies of B. braunii are free-floating, large $(100 \mu \mathrm{m}-$ $500 \mu \mathrm{m}$ in diameter), sometimes forming several dense clusters of subcolonies with indefinite shapes. Subcolonies are often attached to each other by thread-like mucilaginous connections (Figure 2d). Guy-Ohlson and Lindström (1994) described this as 'branching' of the colonies. Temperley (1936) found that branching usually occurs when the colony is about $30 \mu \mathrm{m}$ in diameter and composed of 30 individual cells. In other cases, the refringent threads, linking the clusters, are absent (Metzger \& Largeau 2005). The entire colony is imbedded in a mucilaginous matrix composed of fatty acids that add buoyancy to the colony. Individual semi-transparent cells are oval to pyriform in shape (Figure 2e) and surrounded by a cellulose wall. Cell size (length $\times$ width) is in the range of $(8-9 \times 5) \mu \mathrm{m}$ to $(13 \times 7-9) \mu \mathrm{m}$ (Liu, Sun \& Gerken 2014). Each cell is embedded in a cupshaped base (Figure 2e). The cups are at least two thirds of the cell length with the tips of the cells emerging from the cups. The cups are initially very thin, but increase in thickness with consecutive cell divisions (Guy-Ohlson \& Lindström 1994).

\section{Distribution and ecology}

Living members of the genus Botryococcus are described from all continents (Figure 1), except Antarctica, but paleoecological 
studies do indicate the presence of fossil forms of Botryococcus in the Lidkvarvet Mountains in Antarctica (Guy-Ohlson \& Lindström 1994). Figure 1 illustrates that $B$. braunii has been recorded from 12 African countries, of which only three (South Africa, Namibia and Mozambique) are located in southern Africa (Figure 1). This article represents a first record of the presence of $B$. braunii in Namibia.

Botryococcus braunii occupies a variety of aquatic habitats, ranging from ditches, bog pools, open water tanks, ponds and freshwater and brackish lakes (John \& Tsarenko 2002). These water bodies are situated in temperate, alpine or tropical zones all over the world (Komárek \& Marvan 1992; Wake \& Hillen 1980). B. braunii can tolerate wide ranges of several physico-chemical parameters, thus accounting for its cosmopolitan distribution. Several studies have proven that the species can tolerate wide ranges of temperature (Labib et al. 2014; Qin 2005), salinity (Ranga Rao et al. 2007) and pH (Dayananda et al. 2005). High concentrations of nutrients and alkalinity were found during a $B$. braunii bloom in the Banglang Reservoir in Thailand (Ariyadej et al. 2004) and it also formed blooms in the eutrophic lake Liyu (Taiwan, Chiang et al. 2004) and Tomahawk Lagoon No. 2 in New Zealand (Mitchell 1975).

Botryococcus braunii blooms are known to excrete a mixture of fatty acids, including $\alpha$-linolenic, oleic, linolic and palmitic acids, that have allelopathic effects inhibiting the growth of zooplankton (Chiang et al. 2004; Papa et al. 2008) and causing lysis of phytoplankton (Wu et al. 2006), thereby reducing biodiversity of the water body. A visible rusty-coloured bloom, associated by massive fish kills, was described by Labib et al. (2014) in Nozha Lake, Egypt. Fish kills, accompanying blooms of $B$. braunii, were also recorded in Liyu Lake in Taiwan by Chiang et al. (2004). No fish-kills were, however, experienced at the time of the B. braunii bloom in Namibia.

Besides the fact that the presence of B. braunii blooms may cause alarm among people when high enough densities rapidly change the colour of the water from green to red or burnt orange, people are also sometimes alarmed as these blooms can look very much like a gasoline spill or oil slick, because of the high amounts of lipids secreted by the algae. The bloom in Namibia turned the water a rusty orange-red colour and a thick layer of algae was floating on the surface as a result of density differences caused by the lipids. The orange discolouration of the water may be an indication that the species belongs to the orange pigment-producing chemical 'Race B' strain recognised by Senousy et al. (2004) from Lake Ayamé, Côte d'Ivoire, West Africa. Confirmation of this race would, however, require an 18S rRNA sequence data analysis.

\section{New record}

NAMIBIA. Omaheke region: Tilda Viljoen Dam near Gobabis, 22 26'42.21"S, 18 57'26.21"E, 15 November 2017, Almirall 1 (PUC) (Figure 2).

\section{Conclusions}

Botryococcus braunii, a species that is potentially damaging to indigenous biodiversity of phytoplankton, zooplankton and fish, has been recorded from a freshwater dam in Namibia. This represents the first record of its presence in Namibia and the third record for a country in southern Africa.

\section{Acknowledgements}

We are grateful to Lothar Krienitz from the Leibniz Institute of Freshwater Ecology and Inland Fisheries, Berlin, for confirming the identity of the species.

\section{Competing interests}

The authors declare that they have no financial or personal relationships that may have inappropriately influenced them in writing this article.

\section{Authors' contributions}

S.J.v.V. identified the specimen and wrote the text. A.L. conducted the geographical distribution survey.

\section{References}

Ariyadej, C., Tansakul, R., Tansakul, P. \& Angsupanich, S., 2004, 'Phytoplankton diversity and its relationships to the physico-chemical environment in the Banglang Reservoir, Yala Province', Songklanakarin Journal of Science and Technology 26(5), 595-607.

Belcher, J.H. \& Fogg, G.E., 1955, 'Biochemical evidence of the affinities of Botryococcus', New Phytologist 54, 81-83. https://doi.org/10.1111/j.1469-8137.1955.tb06160.x

Blackburn, K.B., 1936, 'Botryococcus and the algal coals. I. A reinvestigation of the alga Botryococcus braunii Kützing', Transactions of the Royal Society of Edinburgh 58 , 841-854.

Bockwoldt, K.A., Nodine, E.R., Mihuc, T.B., Shambaugh, A.D. \& Stockwell, J.D., 2017, 'Reduced phytoplankton and zooplankton diversity associated with increased cyanobacteria in lake Champlain, USA', Journal of Contemporary Water Research \& Education 160, 100-118. https://doi.org/10.1111/j.1936-704X.2017.03243.x

Chiang, I.Z., Huang, W.Y. \& Wu, J.T., 2004, 'Allelochemicals of Botryococcus braunii (Chlorophyceae)', Journal of Phycology 40, 474-480. https://doi.org/10.1111/ j.1529-8817.2004.03096.x

Dayananda, C., Sarada, R., Bhattacharya, S. \& Ravishankar, G.A., 2005, 'Effect of media and culture conditions on growth and hydrocarbon production by Botryococcus braunii', Process Biochemistry 40, 3125-3131. https://doi.org/10.1016/j.procbio. 2005.03.006

Guiry, M.D. \& Guiry, G.M., 2018, 'AlgaeBase', World-wide electronic publication National University of Ireland, Galway, viewed 21 May 2018, from http://www. algaebase.org

Guy-Ohlson, D. \& Lindström, S., 1994, 'Paleoecology of the Early Permian strata at Heimefrontfjella, Dronning Maud Land, Antarctica', Antarctic Science 6(4), 507-515. https://doi.org/10.1017/S0954102094000763

John, D.M. \& Tsarenko, P.M., 2002, 'Order Chlorococcales', in D.M. John, B.A. Whitton \& A.J Brook (eds.), The freshwater algal flora of the British Isles. An identification guide to freshwater and terrestrial algae, p. 702, Cambridge University Press, Cambridge.

John, D.M., Whitton, B.A. \& Brook, A.J., 2002, The freshwater algal flora of the British Isles. An identification guide to freshwater and terrestrial algae, Cambridge University Press, Cambridge, p. 702.

Klebs, G., 1883, 'Über die organisation einiger Flagellaten-Gruppen und ihre Beziehungen zu Algen und Infusorien', Untersuchungen aus dem Botan. Institut in Tübingen 1, 233-262.

Komárek, J. \& Marvan, P., 1992, 'Morphological differences in natural populations of the genus Botryococcus (Chlorophyceae)', Archiv für Protistenkunde 141, 65-100. https://doi.org/10.1016/S0003-9365(11)80049-7

Kützing, F.T., 1849, Species Algarum Lipsiae [Leipzig], F.A. Brockhaus, p. 922, viewed n.d., from http://img.algaebase.org/pdf/8CCBOC030779a1D85AuRCC021765/ 13490.pdf

Labib, W., Mikhail, S.K., Kassem, A.M., El Kassas, M. \& Ahmed, M.M., 2014, 'Blooms of the colonial green algae Botryococcus braunii Kützing associated with massive fish mortality in Nozha lake, Alexandria, Egypt', in H.G. Kim, B. Reguera, G.M. Hallegraeff, C.K. Lee, M.S. Han \& J.K. Choi (eds.), Harmful Algae 2012, The 15th International Conference on Harmful Algae, CECO, Changwon, Gyeongnam, Korea, October 29-November 02, 2012, ISBN 978-87-990827-4-2. 
Liu, J., Sun, Z. \& Gerken, H., 2014, 'Microalgae and bio-energy', in J. Liu, Z. Sun \& H. Gerken (eds.), Recent advances in microalgal biotechnology, p. 003, OMICS Group eBooks, Foster City, CA.

Metzger, P. \& Largeau, C., 2005, 'Botryococcus braunii: A rich source for hydrocarbons and related ether lipids', Applied Microbiology and Biotechnology 66, 486-496. https://doi.org/10.1007/s00253-004-1779-z

Mitchell, S.F., 1975, 'Phosphate, nitrate and chloride in a eutrophic coastal lake in New Zealand', New Zealand Journal of Marine and Freshwater Research 9(2), 183-198. https://doi.org/10.1080/00288330.1975.9515558

Papa, R.D., Wu, J.T., Baldia, S., Cho, C., Cruz, M.A., Saguiguit, A. et al., 2008, 'Blooms of the colonial green algae, Botryococcus braunii Kützing, in Paoay lake, Luzon island, Philippines', Philippine Journal of Systematic Biology 2(1), 21-31.

Pascher, A., 1939, 'Heterokonten', in L. Rabenhorsts (ed.), Kryptogamen-Flora von Deutschland, Österreich und der Schweiz, p. 204, Aufl. 2 Bd. XI, Akad. Verlagsges (1937-1939), Leipzig.

Plain, N., Largeau, C., Derenne, S. \& Couté, A., 1993, 'Variabilité morphologique de Botryococcus braunii (Chlorococcales, Chlorophyta): Corrélations avec les conditions de croissance et la teneur en lipides', Phycologia 32(4), 259-265. https://doi.org/10.2216/i0031-8884-32-4-259.1

Qin, J., 2005, 'Bio-hydrocarbons from algae: Impacts of temperature, light and salinity on algae growth', A report for the Rural Industries Research and Development
Corporation, RIRDC, Publication Number 05/025, p. 26, Rural Industries Research and Development (RIRDC), Barton, Australia.
Rai, U.N., Dwivedi, S., Baghel, V.S., Tripathi, R.D, Shukla, O.P. \& Shukla, M.K., 2007, 'Morphology and cultural behavior of Botryococcus protuberans with notes on the genus', Journal of Environmental Biology 28(2), 1814-1840.

Ranga Rao, A., Dayananda, C., Sarada, R., Shamala, T.R. \& Ravishankar, G.A., 2007, 'Effect of salinity on growth of green alga Botryococcus braunii and its constituents', Bioresource Technology 98, 560-564. https://doi.org/10.1016/j.biortech.2006. 02.007

Senousy, H.H., Beakes, G.W. \& Hack, E., 2004, 'Phylogenetic placement of Botryococcus braunii (Trebouxiaceae) and Botryococcus sudeticus isolate UTEX 2629 (Chlorophyceae)', Journal of Phycology 40, 412-423. https://doi.org/10.1046/ j.1529-8817.2004.03173.x

Temperley, B.N., 1936, 'The boghead controversy and the morphology of the boghead coal', Transactions of the Royal Society of Edinburgh 58, 855-868.

Todd, A.E., Morse, R.E., Marshall, H.G. \& Mulholland, M.R., 2014, 'Emergence of algal blooms: The effects of short-term variability in water quality on phytoplankton abundance, diversity, and community composition in a tidal estuary Microorganisms 2(1), 33-57. https://doi.org/10.3390/microorganisms2010033

Wake, L.V. \& Hillen, L.W., 1980, 'Study of a bloom of the oil-rich alga Botryococcus braunii in the Darwin River reservoir', Biotechnology and Bioengineering 22, 1637-1565. https://doi.org/10.1002/bit.260220808

Wu, J.T., Chiang, Y.R., Huang, W.Y. \& Jane, W.N., 2006, 'Cytotoxic effects of free fatty acids on phytoplankton algae and cyanobacteria', Aquatic Toxicology 80, 338-345. https://doi.org/10.1016/j.aquatox.2006.09.011 